\title{
Fusicoccin Counteracts the Toxic Effect of Cadmium on the Growth of Maize Coleoptile Segments
}

\author{
Renata Kurtyka $\cdot$ Andrzej Kita $\cdot$ Waldemar Karcz
}

Received: 17 September 2010/Accepted: 28 February 2011/Published online: 19 March 2011

(C) The Author(s) 2011. This article is published with open access at Springerlink.com

\begin{abstract}
The effects of cadmium (Cd; $0.1-1000 \mu \mathrm{M})$ and fusicoccin (FC) on growth, $\mathrm{Cd}^{2+}$ content, and membrane potential $\left(E_{\mathrm{m}}\right)$ in maize coleoptile segments were studied. In addition, the $E_{\mathrm{m}}$ changes and accumulation of $\mathrm{Cd}$ and calcium $(\mathrm{Ca})$ in coleoptile segments treated with $\mathrm{Cd}^{2+}$ combined with $1 \mu \mathrm{M}$ FC or $30 \mathrm{mM}$ tetraethylammonium (TEA) chloride $\left(\mathrm{K}^{+}\right.$-channel blocker) were also determined. In this study, the effects of $\mathrm{Ca}^{2+}$-channel blockers [lanthanum (La) and verapamil (Ver)] on growth and content of $\mathrm{Cd}^{2+}$ and $\mathrm{Ca}^{2+}$ in coleoptile segments were also investigated. It was found that $\mathrm{Cd}$ at high concentrations $(100$ and $1000 \mu \mathrm{M})$ significantly inhibited endogenous growth of coleoptile segments and simultaneously measured proton extrusion. FC combined with $\mathrm{Cd}^{2+}$ counteracted the toxic effect of $\mathrm{Cd}^{2+}$ on endogenous growth and significantly decreased $\mathrm{Cd}^{2+}$ content (not the case for $\mathrm{Cd}^{2+}$ at the highest concentration) in coleoptile segments. Addition of $\mathrm{Cd}$ to the control medium caused depolarization of $E_{\mathrm{m}}$, the extent of which was dependent on $\mathrm{Cd}$ concentration and time of treatment with $\mathrm{Cd}^{2+}$. Hyperpolarization of $E_{\mathrm{m}}$ induced by $\mathrm{FC}$ was suppressed in the presence of $\mathrm{Cd}^{2+}$ at $1000 \mu \mathrm{M}$ but not $\mathrm{Cd}^{2+}$ at $100 \mu \mathrm{M}$. It was also found that treatment of maize coleoptile segments with $30 \mathrm{mM}$ TEA chloride caused hyperpolarization of $E_{\mathrm{m}}$ and decreased $\mathrm{Cd}^{2+}$ content in coleoptile segments,
\end{abstract}

R. Kurtyka $(\bowtie) \cdot$ W. Karcz

Department of Plant Physiology, Faculty of Biology

and Environmental Protection, University of Silesia,

Katowice 40-032, Poland

e-mail: renata.kurtyka@us.edu.pl

A. Kita

Department of Analytical Chemistry, Faculty of Chemistry,

University of Silesia, Katowice 40-006, Poland suggesting that, in the same way as for $\mathrm{FC}$, accumulation of $\mathrm{Cd}^{2+}$ was dependent on plasma membrane (PM) hyperpolarization. Similar to FC, TEA chloride also decreased $\mathrm{Ca}^{2+}$ content in coleoptile segments. La and Ver combined with $\mathrm{Cd}^{2+}(100 \mu \mathrm{M})$ significantly decreased Cd content in maize coleoptile segments, but only La completely abolished the toxic effect of $\mathrm{Cd}^{2+}$ on endogenous growth and growth in the presence of FC. Taken together, these results suggest that the mechanism by which FC counteracts the toxic effect of $\mathrm{Cd}^{2+}$ (except at $1000 \mu \mathrm{M} \mathrm{Cd}{ }^{2+}$ ) on the growth of maize coleoptile segments involves both stimulation of $\mathrm{PM} \mathrm{H}^{+}$-ATPase activity by $\mathrm{FC}$ as well as $\mathrm{Cd}^{2+}$ permeable, voltage-dependent $\mathrm{Ca}$ channels, which are blocked by FC and TEA chloride-induced PM hyperpolarization.

Cadmium (Cd) is widely acknowledged as being one of the most phytotoxic agents (reviewed in Das et al. 1997; Sanità di Toppi and Gabbrielli 1999; Seregin and Ivanov 2001; Pál et al. 2006) inhibiting plant growth when present in excess (Sandalio et al. 2001; Wójcik and Tukiendorf 2005; Nouairi et al. 2006; Karcz and Kurtyka 2007; Kurtyka et al. 2008). Because Cd is one of the most readily absorbed and most rapidly translocated heavy metals in plants, it exerts strong toxicity (Di Cagno et al. 1999; Pál et al. 2006). Among other detrimental effects of $\mathrm{Cd}^{2+}$, membrane damage and changes in enzyme activities affecting uptake and transport of mineral nutrients have been reported (Lindberg and Wingstrand 1985; Ros et al. 1990; Fodor et al. 1995; Llamas et al. 2000; Gonçalves et al. 2009). Several reports have shown that $\mathrm{Cd}^{2+}$ caused a decrease of $\mathrm{K}^{+}$content in various plant materials (Rubio et al. 1994; Llamas et al. 2000; Kurtyka et al. 2008; Gonçalves et al. 2009). 
Furthermore, it has also been shown that $\mathrm{Cd}$ induces depolarization of membrane potential $\left(E_{\mathrm{m}}\right)$ Kennedy and Gonsalvez 1987; Aidid and Okamoto 1992; Llamas et al. 2000; Pavlovkin et al. 2006; Karcz and Kurtyka 2007), which probably results from decreased plasma membrane (PM) $\mathrm{H}^{+}$-ATPase activity (Ros et al. 1992; Fodor et al. 1995; Astolfi et al. 2003; Kabała et al. 2008), leading to decreased $\mathrm{H}^{+}$extrusion (Astolfi et al. 2003; Karcz and Kurtyka 2007). In contrast to $\mathrm{Cd}^{2+}$, fusicoccin (FC), the fungal toxin produced by Fusicoccum amygdale Del., enhances elongation growth by stimulating $\mathrm{H}^{+}$efflux driven by $\mathrm{PM} \mathrm{H} \mathrm{H}^{+}$-ATPase (Marré 1979; Kutschera and Schopfer 1985; Lüthen et al. 1990; Hager et al. 1991; Karcz et al. 1995; Palmgren 1998; Karcz and Burdach 2002; Hager 2003). Simultaneously with FC-induced proton extrusion, hyperpolarization of the PM is observed (Cleland et al. 1977; Karcz and Burdach 2007), which in turn activates an inwardly rectifying $\mathrm{K}^{+}$channel $\left(\mathrm{K}_{\mathrm{in}}^{+}\right)$ (Philippar et al. 1999; Tode and Lüthen 2001). It is also establishes that an FC-binding site arises from interaction of the 14-3-3 protein dimer with the C-terminal autoinhibitory domain of the $\mathrm{H}^{+}$-ATPase and that FC stabilizes this complex (Jahn et al. 1997; Baunsgaard et al. 1998; Fuglsang et al. 1999; Oecking and Hagemann 1999; Würtele et al. 2003). Taking into account that FC causes effects opposite to those produced by $\mathrm{Cd}$, it was interesting to study whether this phytotoxin is able to counteract the toxic effect of $\mathrm{Cd}$ on the growth of maize coleoptile segments. This experimental design can provide new data on the toxic effects of $\mathrm{Cd}$ on plant growth.

The main goal of our experiments was to study the mechanisms of $\mathrm{Cd}$-induced inhibition of elongation growth and the mechanism of $\mathrm{Cd}$ uptake. This goal was realized by: (1) studying the effects of $\mathrm{Cd}^{2+}$ on growth in the presence or absence of FC while simultaneously measuring growth-medium $\mathrm{pH}$ changes; (2) establishing $E_{\mathrm{m}}$ changes in parenchymal cells treated with $\mathrm{Cd}^{2+}$ or $\mathrm{Cd}^{2+}$ applied together with FC and tetraethylammonium (TEA) chloride; (3) determining $\mathrm{Cd}^{2+}$ and $\mathrm{Ca}^{2+}$ content in maize coleoptile segments incubated in medium containing $\mathrm{Cd}^{2+}$ or $\mathrm{Cd}^{2+}$ together with FC and TEA chloride; (4) studying the effects of $\mathrm{Cd}^{2+}$ on both growth and content of $\mathrm{Cd}^{2+}$ and $\mathrm{Ca}^{2+}$ in maize coleoptile segments incubated in the presence of $\mathrm{FC}$ combined with $\mathrm{Ca}^{2+}$-channel blockers [lanthanum chloride (La) and verapamil (Ver)].

\section{Materials and Methods}

\section{Plant Material}

Seeds of maize (Zea mays L. cv. K33 × F2) were soaked in tap water for $2 \mathrm{~h}$, sown on wet wood in plastic boxes, and placed in a growth chamber at $27 \pm 1^{\circ} \mathrm{C}$. The experiments were performed with $10 \mathrm{~mm}$-long coleoptile segments cut from $96 \mathrm{~h}$ old etiolated maize seedlings. Intact coleoptile segments, with the first leaves removed, were excised $3 \mathrm{~mm}$ below the tip and incubated in a control medium made of $1000 \mu \mathrm{M} \mathrm{KCl}, 100 \mu \mathrm{M} \mathrm{NaCl}$, and $100 \mu \mathrm{M} \mathrm{CaCl}$.

\section{Chemicals}

FC (Sigma, USA) was dissolved in ethanol and added to the incubation medium at a final concentration of $1 \mu \mathrm{M}$. The maximal ethanol concentration of $0.2 \%$ did not affect growth of coleoptile segments (data not shown). $\mathrm{CdCl}_{2} \cdot 2.5$ $\mathrm{H}_{2} \mathrm{O}$ (Fluka, Switzerland) was dissolved in control medium. TEA chloride (Sigma, USA), La (Sigma, USA), and Ver (Sigma, USA) were dissolved in deionized water and used at a final concentration of $30 \mathrm{mM}, 5 \mathrm{mM}$, and $50 \mu \mathrm{M}$, respectively. Stock solutions of TEA chloride, La, and Ver were prepared in concentrations that were 100-fold greater compared with those used in the experiments.

\section{Growth and $\mathrm{pH}$ Measurements}

Growth experiments were performed using an apparatus that allowed simultaneous measurement of elongation growth and $\mathrm{pH}$ of the incubation medium from the same tissue sample (Karcz et al. 1990; Karcz and Burdach 2002, 2007). The optical system used for growth measurement (shadow graph methods) permitted recording of the longitudinal extension of a stack of 21 segments. In this setup, the segments, after their excision, were incubated in $6.3 \mathrm{~cm}^{3}\left(0.3 \mathrm{~cm}^{3}\right.$ segment $\left.{ }^{-1}\right)$ of an intensively aerated control medium $(1000 \mu \mathrm{M} \mathrm{KCl}, 100 \mu \mathrm{M} \mathrm{NaCl}$, and $100 \mu \mathrm{M} \mathrm{CaCl} 2$ ). As described previously by Karcz et al. (1995) and by Karcz and Burdach (2002), in this system the incubation medium also flowed through the lumen of the coleoptile cylinders. This feature permitted treatment solutions to be in direct contact with the interior of the segments, which significantly enhanced both the elongation growth of coleoptile segments as well as proton secretion (Karcz et al. 1995).

All manipulations and growth experiments were conducted under dim green light. The temperature of all solutions in the elongation and $\mathrm{pH}$-measuring system was thermostatically controlled at $25 \pm 0.5^{\circ} \mathrm{C}$. $\mathrm{pH}$ measurements were performed with a $\mathrm{pH}$ meter (type CI-316; Elmetron, Poland) and pH electrode (OSH 10-10; Metron, Poland). Cd, FC, and calcium (Ca)-channel blockers (La or Ver) were introduced into the incubation medium at 120 min into the experiment. The initial $\mathrm{pH}$ of the incubation solution was adjusted to 5.8-6.0 with either $0.1 \mathrm{M}$ $\mathrm{NaOH}$ or $0.1 \mathrm{M} \mathrm{HCl}$. 
Electrophysiology

The electrophysiological experiments were carried out with intact, $10 \mathrm{~mm}$-long coleoptile segments that were prepared the same as for the growth experiments. $E_{\mathrm{m}}$ was measured by recording the voltage between a $3 \mathrm{M} \mathrm{KCl-filled} \mathrm{glass}$ micropipette inserted into the parenchymal cells and a reference electrode in the bathing medium containing the same composition as used in the growth experiments. For electrophysiological experiments, the segments were preincubated for $2 \mathrm{~h}$ in an intensively aerated bathing medium, whereupon the segments were transferred into a perfusion Plexiglass chamber mounted on a vertically placed microscope stage. The microelectrodes were inserted into cells under microscope by means of micromanipulator (Hugo Sachs Electronik; March-Hugstteten, Germany). Medium changes were performed by means of a peristaltic pump (Type Peri-Star PRO; World Precision Instruments, USA), which allowed changing of the bathing medium in the chamber (usually fourfold within $<2 \mathrm{~min}$ ). Micropipettes were pulled on a vertical pipette puller (model L/M-3P-A; List-Medical, Germany) from borosilicate glass capillaries (type 1B150F-3; World Precision Instruments, USA). Tip diameters measured $<1 \mu \mathrm{m}$. $\mathrm{Cd}, \mathrm{FC}$, and TEA chloride were introduced into the control medium after stabilization $(<10 \mathrm{~min})$ of $E_{\mathrm{m}}$.

\section{Determination of $\mathrm{Cd}$ and $\mathrm{Ca}$ Content}

$\mathrm{Cd}$ and $\mathrm{Ca}$ concentrations in maize coleoptile segments were determined by emission spectrometry with excitation by way of an argon inductively coupled plasma technique by means of a Spektroflame-M spectrophotometer (Spectro Analytical Instruments, Germany). Before chemical analysis, 110 intact coleoptile segments were split along the long axis and preincubated for $2 \mathrm{~h}$ in an intensively aerated growth medium (control). The composition and volume $\left(0.3 \mathrm{~cm}^{3}\right.$ segment $\left.{ }^{-1}\right)$ of the incubation medium were the same as that used in the growth experiments. After preincubation of the coleoptile segments, Cd $(0.1-1000 \mu \mathrm{M})$, Cd together with FC $(1 \mu \mathrm{M})$, or TEA chloride $(30 \mathrm{mM})$ were introduced into the incubation medium for $5 \mathrm{~h}$. The variant in which these three components $\left(\mathrm{Cd}^{2+}, \mathrm{FC}\right.$, and TEA chloride) were combined was also studied. Moreover, $\mathrm{Cd}$ and $\mathrm{Ca}$ content in maize coleoptile segments exposed (for $5 \mathrm{~h}$ ) to $100 \mu \mathrm{M} \mathrm{Cd}$ or $\mathrm{Cd}$ combined with $(1 \mu \mathrm{M}) \mathrm{FC}$ or/and Ca-channel blockers (La and Ver) was also determined. In this case, the segments were first preincubated for $2 \mathrm{~h}$ in control medium, whereupon $\mathrm{Cd}$ or $\mathrm{Cd}$ with $\mathrm{FC}$ or/and Ca-channel blockers were added. After each treatment, the halves of the segments were removed from the solution and washed three times with deionized water, whereupon they were dried at $80^{\circ} \mathrm{C}$ to determine dry weight. For $\mathrm{Cd}$ and $\mathrm{Ca}$ analyses, dry plant tissue was mineralized. Each sample (approximately $0.2 \mathrm{~g}$ dry matter) was treated with $5 \mathrm{ml}$ ultrapure concentrated nitric acid (Merck, Germany) and left for $24 \mathrm{~h}$. Next, the samples were digested until complete mineralization was achieved. After mineralization, the samples were diluted with redistilled water to a volume of $10 \mathrm{ml}$. Concentrations of $\mathrm{Cd}$ and $\mathrm{Ca}$ were measured by inductively coupled plasmaatomic emission spectroscopy (frequency $27.12 \mathrm{MHz}$; power $1.0 \mathrm{~kW}$; plasma gas $14.0 \mathrm{l} / \mathrm{min}$; auxiliary gas $0.5 \mathrm{l} / \mathrm{min}$; carrier gas $1 \mathrm{l} / \mathrm{min}$; and analytical line $\mathrm{Cd}^{2+}$ $228.802 \mathrm{~nm}$ and $\mathrm{Ca}^{2+} 422.673 \mathrm{~nm}$ ). As standards for control of the elemental analysis, Virginia tobacco leaves (CTA-VTL-2) were used; the results fit the range of certified recommended values. All experiments concerning the accumulation of $\mathrm{Cd}^{2+}$ and $\mathrm{Ca}^{2+}$ were replicated at least four times, and results are expressed as means \pm SEs.

\section{Statistical Analysis}

Data were analyzed using computer software Statistical for Windows (StatSoft 2008; STATISTICA data analysis software system, version 8.0. http://www.statsoft.com, USA). Differences between individual treatments and control were analyzed using one-way analysis of variance and Fisher's least significant difference (LSD) test. Statistical significance was defined at $P<0.05$.

\section{Results}

Effect of $\mathrm{Cd}^{2+}$ on Endogenous and FC-Induced Growth of Coleoptile Segments Incubated With or Without Ca-Channel Blockers

The effect of $\mathrm{Cd}^{2+}(0.1-1000 \mu \mathrm{M})$ on the growth of maize coleoptile segments incubated in control medium (endogenous growth) is shown in Fig. 1. As can be seen in this figure, $\mathrm{Cd}^{2+}$ applied to the medium (after $2 \mathrm{~h}$; preincubation of segments in control medium) at concentrations of 10,100 , and $1000 \mu \mathrm{M}$ decreased endogenous growth of maize coleoptile segments by 14,40 , and $60 \%$, respectively. However, $\mathrm{Cd}$ at $1 \mu \mathrm{M}$ did not cause any significant changes in endogenous growth $\left(856.8 \pm 32.6 \mu \mathrm{m} \mathrm{cm}^{-1}\right)$ compared with the control $\left(935.0 \pm 43.9 \mu \mathrm{m} \mathrm{cm}^{-1}\right)$. Even the lowest $\mathrm{Cd}$ concentration $(0.1 \mu \mathrm{M})$ used stimulated (by $16 \%$ ) the growth of maize coleoptile segments. The inset in Fig. 1 shows the time courses of the endogenous growth of maize coleoptile segments as a function of $\mathrm{Cd}^{2+}$ concentration.

FC added to the control medium at 120 min rapidly enhanced endogenous growth of maize coleoptile segments (Fig. 2). It was found that FC-induced growth of maize 


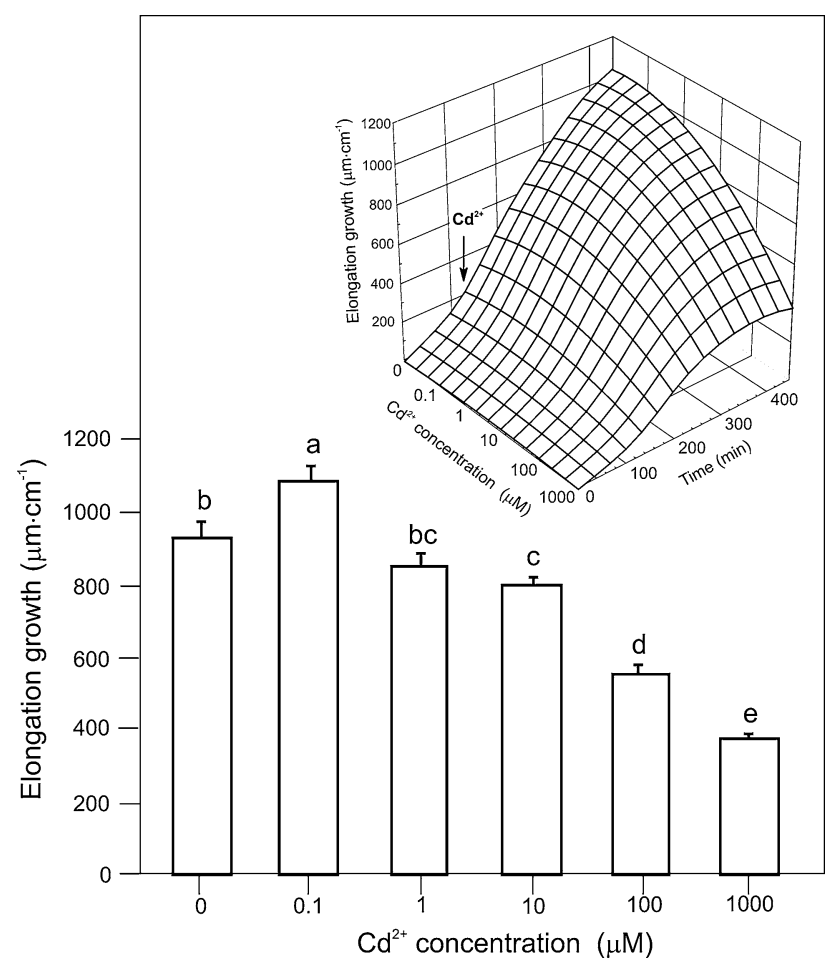

Fig. 1 Effect of $\mathrm{Cd}(0.1-1000 \mu \mathrm{M})$ on the endogenous growth $\left(\mu \mathrm{m} \mathrm{cm}^{-1}\right)$ of maize coleoptile segments. The elongation of a stack of 21 segments was measured as described in Materials and Methods. The growth of maize coleoptile segments after $7 \mathrm{~h}$ is shown $(2 \mathrm{~h}$ of preincubation in control medium plus $5 \mathrm{~h}$ of incubation with $\mathrm{Cd}$ ). The inset shows $\mathrm{Cd}$ dependence of endogenous growth as a function of time. After preincubation $(2 \mathrm{~h})$ of coleoptile segments in control medium, Cd was added (arrow). Values are means of ten independent experiments. Bars indicate means \pm SEs. Statistical analysis (using software Statistica) showed that differences between values of elongation growth for control and $1.0 \mu \mathrm{M} \mathrm{Cd}{ }^{2+}$ were statistically not significant at $420 \mathrm{~min}$ (LSD test $P<0.05$ )

coleoptile segments was enhanced approximately twofold compared with growth seen in control medium. Application of $\mathrm{FC}$ together with $\mathrm{Cd}^{2+}$ counteracted the toxic effect of $\mathrm{Cd}$ on endogenous growth, which means that growth of coleoptile segments in the presence of both substances was always greater than endogenous growth $(935.0 \pm$ $43.9 \mu \mathrm{m} \mathrm{cm}^{-1}$ ). In contrast, $\mathrm{Cd}^{2+}$ at 100 and $1000 \mu \mathrm{M}$ inhibited FC-induced growth by 10 and 30\%, respectively (Fig. 2). Moreover, the data presented here (Fig. 2) show that the growth of coleoptile segments treated with FC combined with $0.1 \mu \mathrm{M} \mathrm{Cd}^{2+}$ was greater than FC-induced growth $\left(1764.5 \pm 67 \mu \mathrm{m} \mathrm{cm}^{-1}\right)$.

When Ver was added to the control medium at $50 \mu \mathrm{M}$, it did not change either endogenous or FC-induced growth of maize coleoptile segments (Fig. 3). However, La at $5 \mathrm{mM}$ significantly stimulated (by 30\%) both endogenous and FCinduced growth. As indicated in Fig. 3, La combined with $\mathrm{Cd}^{2+}$ abolished the toxic effect of $\mathrm{Cd}$ on both endogenous growth and growth in the presence of FC. Compared with

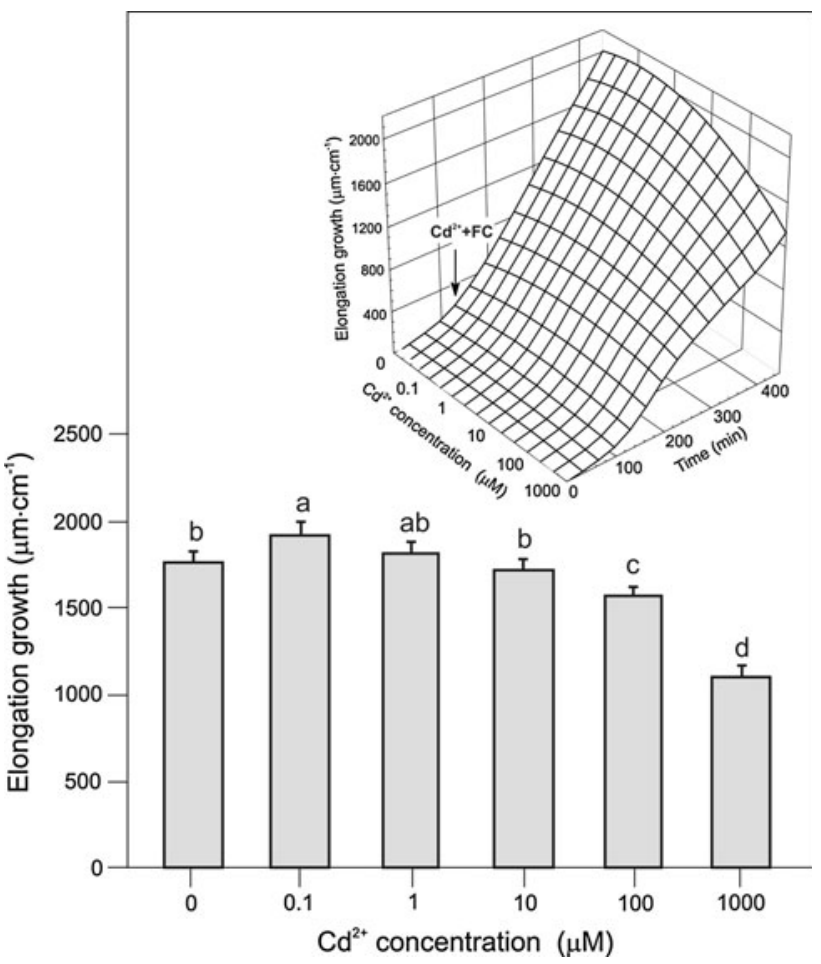

Fig. 2 Effect of $\mathrm{Cd}(0.1-1000 \mu \mathrm{M})$ on growth $\left(\mu \mathrm{m} \mathrm{cm}^{-1}\right)$ of maize coleoptile segments incubated in the presence of $1 \mu \mathrm{M}$ FC. The elongation of a stack of 21 segments was measured as described in Materials and Methods. The growth of maize coleoptile segments after $7 \mathrm{~h}$ is shown $(2 \mathrm{~h}$ of preincubation in control medium plus $5 \mathrm{~h}$ of incubation with $\mathrm{Cd}$ combined with $\mathrm{FC}$ ). The inset shows $\mathrm{Cd}$ dependence of growth in the presence of $\mathrm{FC}$ as a function of time. After preincubation $(2 \mathrm{~h})$ of coleoptile segments in the control medium, Cd combined with FC $(1 \mu \mathrm{M})$ was added (arrow). Values are means of ten independent experiments. Bars indicate means \pm SEs. Means followed by the same letter are not significantly different from each other (LSD test $P<0.05$ )

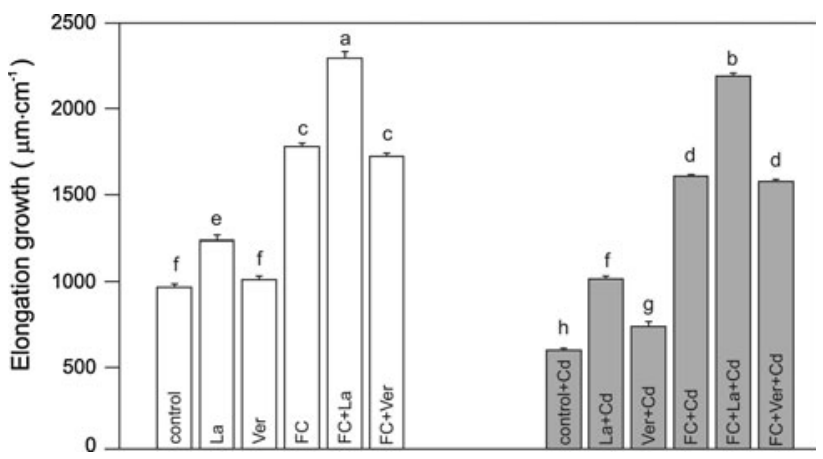

Fig. 3 Effect of $100 \mu \mathrm{M} \mathrm{Cd}$ on endogenous and FC-induced growth $\left(\mu \mathrm{m} \mathrm{cm}^{-1}\right)$ of maize coleoptile segments incubated in the presence of Ca-channel blockers ( $\mathrm{La}$ and Ver). Values are means of five independent experiments. Bars indicate means \pm SEs. Means followed by the same letter are not significantly different from each other (LSD test $P<0.05$ ) 


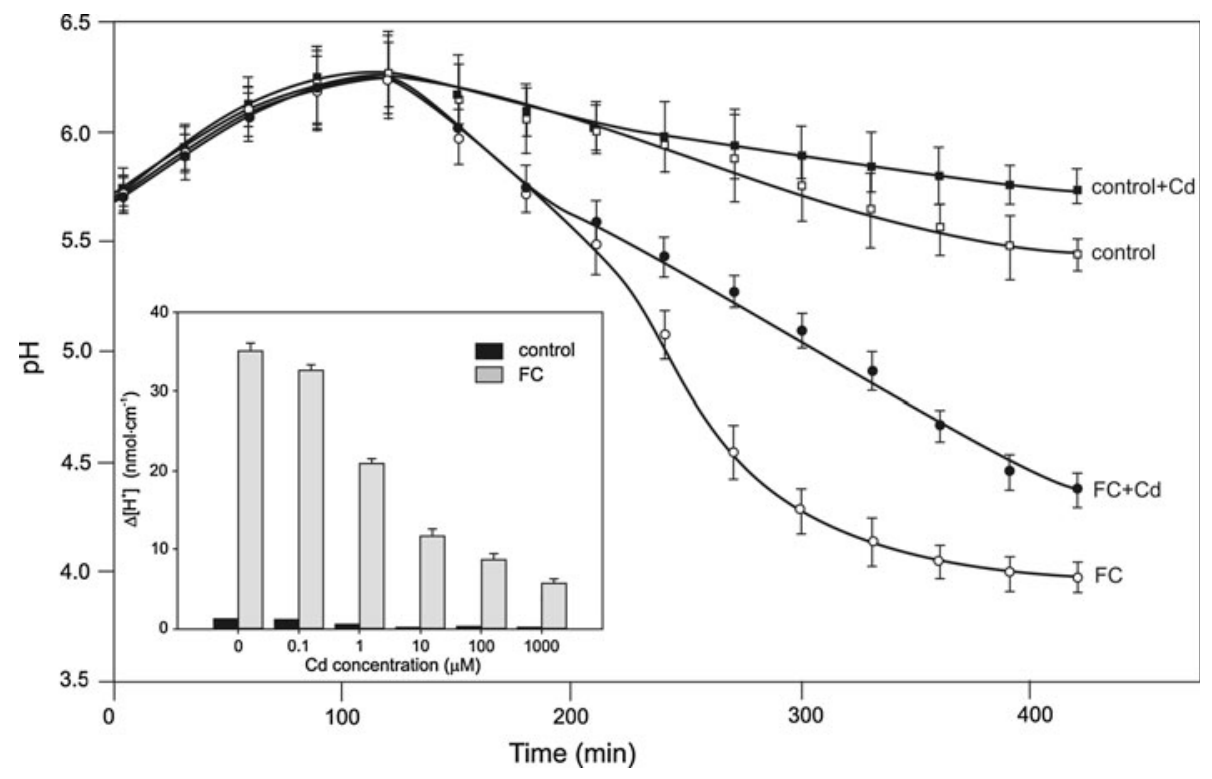

Fig. 4 Effect of $100 \mu \mathrm{M} \mathrm{Cd}$ on $\mathrm{pH}$ changes of the incubation medium measured simultaneously (using the same tissue sample) with endogenous growth and growth in the presence of FC $(1 \mu \mathrm{M})$. The segments were first preincubated $(2 \mathrm{~h})$ in control medium, whereupon FC, $\mathrm{Cd}$, or $\mathrm{Cd}$ together with FC were added (arrow). Values for $\mathrm{pH}$ are means of ten independent experiments. Bars indicate

La, Ver did not abolish the toxic effect of $\mathrm{Cd}^{2+}$ on FCinduced growth, and it only partly diminished the inhibitory effect of $\mathrm{Cd}^{2+}$ on endogenous growth (Fig. 3).

Effect of $\mathrm{Cd}^{2+}$ on pH Changes of the Incubation Medium

$\mathrm{pH}$ changes of the incubation medium were measured simultaneously with the elongation growth of coleoptile segments. The data in Fig. 4 indicate that coleoptile segments incubated in control medium characteristically changed the medium's $\mathrm{pH}$; usually within the first $2 \mathrm{~h}$ an increase in $\mathrm{pH}$ to $6.0-6.5$ was observed, followed by a slow decrease in $\mathrm{pH}$ to approximately 5.5 after $7 \mathrm{~h}$. When FC was added (after $2 \mathrm{~h}$ of preincubation) to the control medium, an additional decrease in $\mathrm{pH}$ to 4.0 was observed. However, when $\mathrm{Cd}^{2+}$ alone (at concentrations $>0.1 \mu \mathrm{M}$ ) or $\mathrm{Cd}^{2+}$ together with FC was added at 120 min, significant suppression of medium acidification was found (Fig. 4 inset). For example, the $\mathrm{H}^{+}$concentration in the medium found in the presence of $\mathrm{Cd}^{2+}(100 \mu \mathrm{M})$ combined with FC was approximately fourfold lower than with FC alone (Fig. 4 inset).

Effect of $\mathrm{Cd}^{2+}, \mathrm{FC}$, and TEA Chloride on $E_{\mathrm{m}}$

$\mathrm{Cd}^{2+}$ ions administered into the control medium caused depolarization of $E_{\mathrm{m}}$, the extent of which was dependent means \pm SEs. To avoid illegibility of the figure, only some curves have been shown. The inset shows $\mathrm{Cd}$ dependence of medium $\mathrm{pH}$ expressed as $\Delta\left[\mathrm{H}^{+}\right]$, where $\Delta\left[\mathrm{H}^{+}\right]$indicates the difference between $\mathrm{H}^{+}$concentration $\left[\mathrm{H}^{+}\right]$at 420 and $120 \mathrm{~min}$. The differences between $\mathrm{pH}$ values for control medium, $\mathrm{FC}, \mathrm{Cd}$, or $\mathrm{Cd}$ combined with $\mathrm{FC}$ were statistically significant at $420 \mathrm{~min}(\mathrm{LSD}$ test $P<0.05)$

on $\mathrm{Cd}^{2+}$ concentration and time after its addition (Table 1). For example, treatment of parenchymal cells of maize coleoptile segments with 100 or $1000 \mu \mathrm{M} \mathrm{Cd}{ }^{2+}$ caused depolarization of $E_{\mathrm{m}}$ by 55 and $67 \mathrm{mV}$, respectively. In turn, addition of FC to the control medium caused immediate hyperpolarization of $E_{\mathrm{m}}$ by $23 \mathrm{mV}$ (from $-121 \pm 4.1$ to $-144 \pm 6.2 \mathrm{mV}$ ). This hyperpolarization of $E_{\mathrm{m}}$ was suppressed in the presence of $\mathrm{Cd}^{2+}$ at $1000 \mu \mathrm{M}$ but not with $\mathrm{Cd}^{2+}$ at $100 \mu \mathrm{M}$ (Table 1). $\mathrm{Cd}^{2+}$ at $1000 \mu \mathrm{M}$ not only suppressed FC-induced hyperpolarization of the $E_{\mathrm{m}}$ but also caused additional membrane depolarization.

TEA chloride applied to the control medium caused hyperpolarization of $E_{\mathrm{m}}$, during which $E_{\mathrm{m}}$ became $33.2 \pm 4.0 \mathrm{mV}$ more negative than the original potential $(-116.1 \pm 4.6 \mathrm{mV})$ (Table 1). TEA chloride combined with $\mathrm{Cd}^{2+}$ counteracted this $\mathrm{Cd}^{2+}$-induced depolarization of $E_{\mathrm{m}}$ (Table 1). Interestingly, $\mathrm{Cd}^{2+}$ at the highest concentration $(1000 \mu \mathrm{M})$, but not $\mathrm{Cd}^{2+}$ at $100 \mu \mathrm{M}$, suppressed hyperpolarization of $E_{\mathrm{m}}$ induced by TEA chloride. When FC and TEA chloride were combined, they did not cause any additional effect on $E_{\mathrm{m}}$ compared with that induced by each substance separately. In turn, combined FC, TEA chloride, and $\mathrm{Cd}^{2+}$ counteracted depolarization of $E_{\mathrm{m}}$ induced by $\mathrm{Cd}^{2+}$ (Table 1). This was similar to TEA chloride applied only with $\mathrm{Cd}^{2+}$, but it was not the case for $\mathrm{FC}$ applied with $\mathrm{Cd}^{2+}$ at $1000 \mu \mathrm{M}$. 
Table $1 \mathrm{E}_{\mathrm{m}}$ changes of parenchymal coleoptile cells with addition of $\mathrm{Cd}(100$ and $1000 \mu \mathrm{M})$ and $\mathrm{Cd}$ together with $\mathrm{FC}(1 \mu \mathrm{M})$ and/or $30 \mathrm{mM}$ TEA chloride

\begin{tabular}{|c|c|c|c|c|}
\hline \multirow[t]{2}{*}{ Treatments } & \multicolumn{4}{|l|}{$\mathrm{E}_{\mathrm{m}}(\mathrm{mV})$} \\
\hline & $\begin{array}{l}\mathrm{E}_{\mathrm{m}} \text { after stabilization } \\
\text { in control medium (time } 0 \text { ) }\end{array}$ & $\mathrm{E}_{\mathrm{m}}$ after $20 \mathrm{~min}$ & $\mathrm{E}_{\mathrm{m}}$ after $40 \mathrm{~min}$ & $\mathrm{E}_{\mathrm{m}}$ after $60 \mathrm{~min}$ \\
\hline FC & $-121.0 \pm 4.1$ & $-137.0 \pm 5.5$ & $-144.2 \pm 5.1$ & $-144.0 \pm 6.2$ \\
\hline TEA chloride & $-116.1 \pm 4.6$ & $-123.8 \pm 5.7$ & $-152.3 \pm 4.8$ & $-149.3 \pm 4.0$ \\
\hline TEA chloride + FC & $-117.0 \pm 6.2$ & $-129.1 \pm 5.5$ & $-146.2 \pm 11.7$ & $-146.2 \pm 11.9$ \\
\hline $\mathrm{Cd}(100 \mu \mathrm{M})$ & $-119.5 \pm 8.4$ & $-112.8 \pm 5.3$ & $-68.0 \pm 3.2$ & $-64.4 \pm 3.3$ \\
\hline $\mathrm{FC}+\mathrm{Cd}$ & $-118.8 \pm 4.3$ & $-134.2 \pm 7.5$ & $-145.3 \pm 7.2$ & $-142.0 \pm 8.5$ \\
\hline TEA chloride $+\mathrm{Cd}$ & $-114.5 \pm 6.3$ & $-127.7 \pm 6.1$ & $-149.7 \pm 6.8$ & $-143.4 \pm 7.3$ \\
\hline TEA chloride $+\mathrm{FC}+\mathrm{Cd}$ & $-115.4 \pm 5.0$ & $-121.6 \pm 4.7$ & $-144.1 \pm 6.3$ & $-146.0 \pm 7.9$ \\
\hline $\mathrm{Cd}(1000 \mu \mathrm{M})$ & $-122.0 \pm 7.7$ & $-102.6 \pm 4.2$ & $-55.9 \pm 1.8$ & $-55.1 \pm 2.6$ \\
\hline $\mathrm{FC}+\mathrm{Cd}$ & $-120.6 \pm 8.1$ & $-117.8 \pm 4.5$ & $-72.5 \pm 3.8$ & $-60.5 \pm 3.5$ \\
\hline TEA chloride + Cd & $-119.2 \pm 6.6$ & $-128.6 \pm 8.5$ & $-136.3 \pm 7.5$ & $-125.9 \pm 6.3$ \\
\hline TEA chloride $+\mathrm{FC}+\mathrm{Cd}$ & $-121.4 \pm 8.4$ & $-130.7 \pm 8.2$ & $-134.9 \pm 8.2$ & $-128.7 \pm 6.9$ \\
\hline
\end{tabular}

At time 0 , the control medium was changed for a new one, at the same salt composition, containing Cd, FC, TEA chloride, or Cd together with FC or/and TEA chloride. $\mathrm{E}_{\mathrm{m}}$ was measured continuously after $2 \mathrm{~h}$ of segment preincubation in control medium. Data are means of at least five independent experiments. Error indicates means \pm SEs

\section{$\mathrm{Cd}$ and $\mathrm{Ca}$ Content in Maize Coleoptile Segments}

$\mathrm{Cd}$ and $\mathrm{Ca}$ content in maize coleoptile segments was also determined (Figs. 5, 6, 7). It was found that Cd content in maize coleoptile segments depended on $\mathrm{Cd}$ concentration in the control medium. An increase in $\mathrm{Cd}$ concentration from 10 to $100 \mu \mathrm{M}$ caused an approximately 11-fold increase of its accumulation in maize coleoptile segments, whereas an increase in $\mathrm{Cd}^{2+}$ concentration from 100 to $1000 \mu \mathrm{M}$ caused only a 2.3-fold increase of $\mathrm{Cd}^{2+}$ tissue content (Fig. 5). When FC was combined with $\mathrm{Cd}^{2+}$ at $100 \mu \mathrm{M}$, a $50 \%$ decrease of the $\mathrm{Cd}$ accumulation in coleoptile segments [from $1901 \pm 103$ to $895 \pm 27 \mathrm{mg} \mathrm{kg}^{-1}$ dry mass $(\mathrm{dm})$ ]

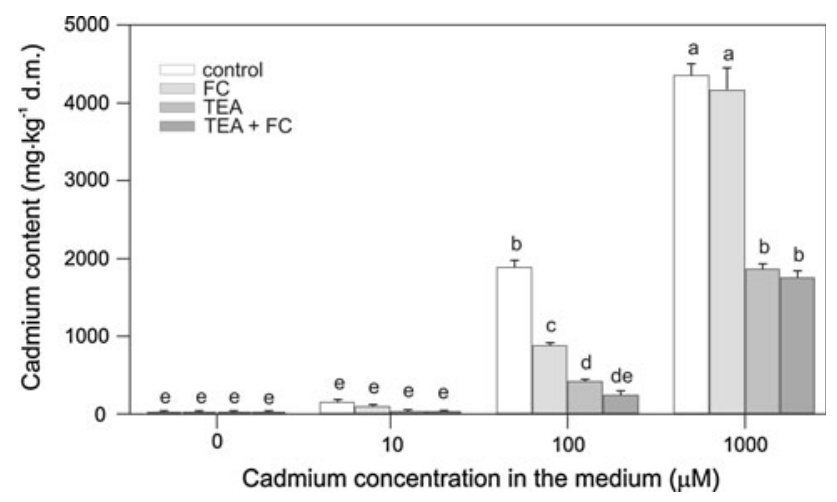

Fig. $5 \mathrm{Cd}$ content in maize coleoptile segments exposed $(5 \mathrm{~h})$ to either 10, 100, or $1000 \mu \mathrm{M} \mathrm{Cd}$, Cd combined with FC $(1 \mu \mathrm{M})$, and/or $30 \mathrm{mM}$ TEA. The segments were first preincubated $(2 \mathrm{~h})$ in control medium, whereupon $\mathrm{Cd}$ or $\mathrm{Cd}$ with $\mathrm{FC}$ or/and TEA were added. Results are the means of four independent experiments. Bars indicate means \pm SEs. Means followed by the same letter are not significantly different from each other (LSD test $P<0.05$ ) was observed compared with the segments treated with $\mathrm{Cd}^{2+}$ alone. FC did not change the content of $\mathrm{Cd}^{2+}$ in coleoptile segments treated with $\mathrm{Cd}^{2+}$ at $1000 \mu \mathrm{M}$. Furthermore, the effect of TEA chloride on $\mathrm{Cd}^{2+}$ and $\mathrm{Ca}^{2+}$ accumulation in segments of maize coleoptiles was also studied. These results indicate that TEA chloride decreased accumulation of both elements (Figs. 5, 6). In segments treated with TEA chloride combined with 100 or $1000 \mu \mathrm{M} \mathrm{Cd}^{2+}, \mathrm{Cd}^{2+}$ content was relatively lower compared with segments treated with $\mathrm{Cd}$ alone. As illustrated in Fig. 6, a total $\mathrm{Ca}^{2+}$ content of $573.32 \pm 49.9 \mathrm{mg} \mathrm{kg}^{-1}(\mathrm{dm})$ was decreased approximately twofold after TEA chloride application. The application of TEA chloride together with $\mathrm{FC}$ or/and $\mathrm{Cd}^{2+}$ to the control medium led to significant decrease $(P<0.05)$ in Cd (Fig. 5) and $\mathrm{Ca}$ concentrations (Fig. 6).

Interestingly, $\mathrm{FC}$ alone or $\mathrm{FC}$ combined with $\mathrm{Cd}^{2+}$ decreased $\mathrm{Ca}$ content in maize coleoptile segments (Fig. 6). In addition, $\mathrm{Cd}^{2+}$ at the highest concentration $(1000 \mu \mathrm{M})$ decreased $\mathrm{Ca}$ content by $50 \%$, probably as a result of $\mathrm{Cd}$ competitively inhibiting $\mathrm{Ca}$ uptake. Both $\mathrm{FC}$ and Ca-channel blockers ( $\mathrm{La}$ and Ver) significantly decreased (LSD test $P<0.05) \mathrm{Cd}$ content in maize coleoptile segments (Fig. 7). La and Ver practically did not change $\mathrm{Ca}$ content in maize coleoptile segments (data not shown).

\section{Discussion}

Despite there being much research on Cd toxicity, our knowledge concerning the effect of this heavy metal on 


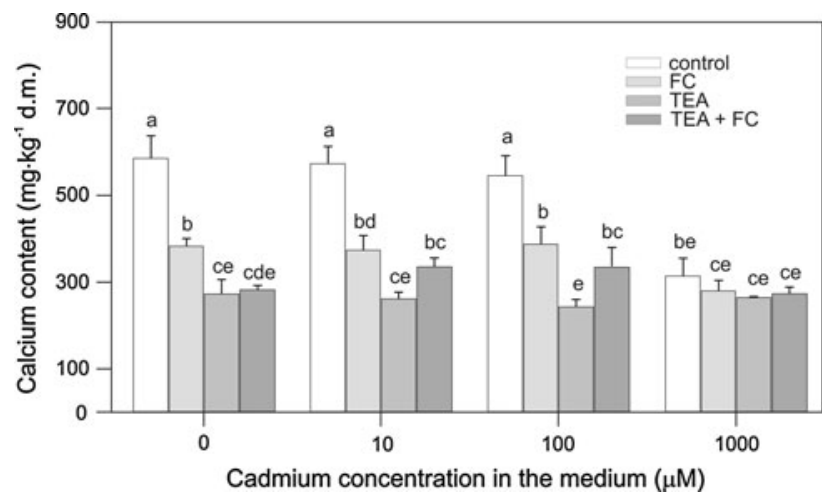

Fig. $6 \mathrm{Ca}$ content in maize coleoptile segments exposed $(5 \mathrm{~h})$ to either 10,100 , or $1000 \mu \mathrm{M} \mathrm{Cd}$, Cd combined with FC $(1 \mu \mathrm{M})$, and/or $30 \mathrm{mM}$ TEA. The segments were first preincubated $(2 \mathrm{~h})$ in control medium, whereupon $\mathrm{Cd}$ or $\mathrm{Cd}$ with $\mathrm{FC}$ or/and TEA were added. Results are the means of four independent experiments. Bars indicate means \pm SEs. Means followed by the same letter are not significantly different from each other (LSD test $P<0.05$ )

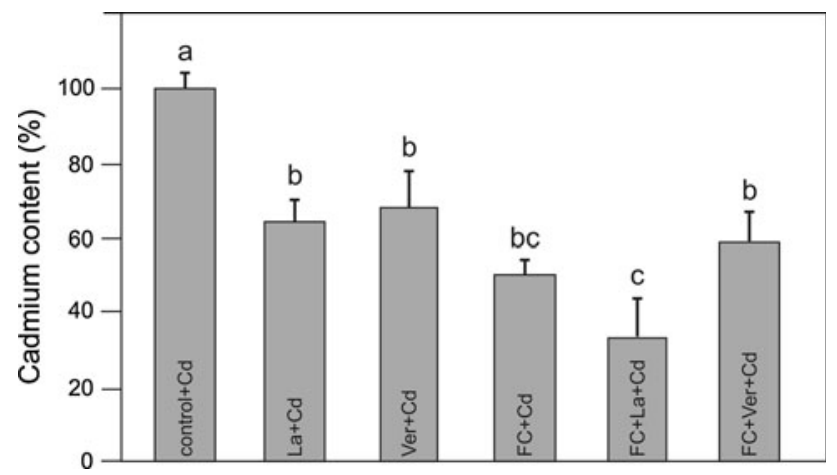

Fig. $7 \mathrm{Cd}$ content in maize coleoptile segments exposed $(5 \mathrm{~h})$ to either $100 \mu \mathrm{M} \mathrm{Cd}$, Cd combined with FC $(1 \mu \mathrm{M})$, and/or Ca-channel blockers (La and Ver). The segments were first preincubated $(2 \mathrm{~h})$ in control medium, whereupon $\mathrm{Cd}$ or $\mathrm{Cd}$ with $\mathrm{FC}$ or/and Ca-channel blockers (La and Ver) were added. Results are the means of four independent experiments. Bars indicate means \pm SEs. Means followed by the same letter are not significantly different from each other (LSD test $P<0.05$ )

plant growth is still limited. The main goal of this work was to determine the mechanisms of Cd-induced inhibition of elongation growth as well as the mechanism of $\mathrm{Cd}$ uptake.

It is currently well established that an FC-binding site arises from the interaction of 14-3-3 protein dimer with the C-terminal autoinhibitory domain of $\mathrm{PM} \mathrm{H}^{+}$-ATPase, and FC stabilizes this complex, thus causing an increase in proton pump activity (Jahn et al. 1997; Baunsgaard et al. 1998; Fuglsang et al. 1999; Oecking and Hagemann 1999; Würtele et al. 2003). The data presented in this article, i.e., that FC causes (1) acceleration of elongation growth compared with endogenous growth (Figs. 1, 2), (2) enhancement of proton extrusion compared with FC-free medium (Fig. 4), and (3) immediate hyperpolarization of the PM
(Table 1), are in good agreement with the results obtained by other investigators (Cleland et al. 1977; Kutschera and Schopfer 1985; Felle 1989; Lüthen et al. 1990; Rück et al. 1993; Karcz and Burdach 2002; Hager 2003; Karcz and Burdach 2007).

The simultaneous measurements of elongation growth and $\mathrm{pH}$ level of the incubation medium showed that in maize coleoptile segments, $\mathrm{Cd}^{2+}$ at $>1 \mu \mathrm{M}$ produced a significant inhibition of endogenous growth (Fig. 1) as well as a decrease in proton extrusion (Fig. 4). $\mathrm{Cd}^{2+}$ also caused depolarization of $E_{\mathrm{m}}$ (Table 1). These findings match strikingly with $\mathrm{Cd}^{2+}$ content in maize coleoptile segments (Figs. 5, 7) and support the results of our previous experiments (Karcz and Kurtyka 2007). It should be pointed out that the large range of $\mathrm{Cd}$ concentrations used in our experiments showed that concentrations effectively producing growth inhibition are high compared with concentrations usually found in soil solutions. This discrepancy, among others, results from the fact that in the case of environmental studies, durations of growth experiments are usually significantly longer compared with studies using a model system, such as coleoptile segments, which, as our experiments showed, need greater $\mathrm{Cd}$ concentration. The inhibition of proton extrusion and depolarization of $E_{\mathrm{m}}$ observed here in the presence of $\mathrm{Cd}^{2+}$ are in line with the findings of other investigators, who reported an inhibition of PM H $\mathrm{H}^{+}$-ATPase (Ros et al. 1992; Fodor et al. 1995; Astolfi et al. 2003) and depolarization of $E_{\mathrm{m}}$ by $\mathrm{Cd}^{2+}$ (Kennedy and Gonsalvez 1987; Aidid and Okamoto 1992; Llamas et al. 2000; Pavlovkin et al. 2006).

Addition of $\mathrm{FC}$ together with $\mathrm{Cd}^{2+}$ counteracted the toxic effect of $\mathrm{Cd}$ on endogenous growth (growth in control) of maize coleoptile segments, although $\mathrm{Cd}^{2+}$ at concentrations of 100 and $1000 \mu \mathrm{M}$ inhibited FC-induced growth by 10 and 30\%, respectively (Fig. 2). The first phenomenon is probably due to stimulation of the segment elongation by FC, which, according to the "acid growth theory," enhances growth by stimulating proton extrusion through $\mathrm{PM} \mathrm{H} \mathrm{H}^{+}$-ATPase. It is suggested that this proton extrusion is large enough to overcome the toxic effect of $\mathrm{Cd}^{2+}$ on endogenous growth (Fig. 4). In contrast, $\mathrm{Cd}^{2+}$ at concentrations of 100 and $1000 \mu \mathrm{M}$ diminished FCinduced growth and proton extrusion, probably as a result of $\mathrm{PM} \mathrm{H}^{+}$-ATPase inhibition. This last suggestion is also supported by the experiments in which FC-induced $E_{\mathrm{m}}$ hyperpolarization was suppressed by $\mathrm{Cd}^{2+}$ at a concentration of $1000 \mu \mathrm{M}$. Until now, there has been no doubt that FC-induced PM hyperpolarization is a consequence of a stimulated proton extrusion through $\mathrm{PM} \mathrm{H}^{+}$-ATPase (Cleland et al. 1977; Marré 1979; Kutschera and Schopfer 1985; Karcz et al. 1995; Karcz and Burdach 2007).

The results presented here also show that FC combined with $\mathrm{Cd}^{2+}$ at $100 \mu \mathrm{M}$ decreased (by 50\%) Cd content in 
maize coleoptile segments (Figs. 5, 7). This lower $\mathrm{Cd}^{2+}$ concentration could also decrease the toxic effect of $\mathrm{Cd}^{2+}$ (at least for $\mathrm{Cd}^{2+}$ at $100 \mu \mathrm{M}$ ) on elongation growth of coleoptile segments. In the case of greater $\mathrm{Cd}^{2+}$ concentration $(1000 \mu \mathrm{M}), \mathrm{FC}$ (but not TEA chloride) was not effective in either recovering $\mathrm{Cd}^{2+}$-induced membrane depolarization or decreasing Cd content in maize coleoptile cells. This finding is probably due to irreversible inhibition

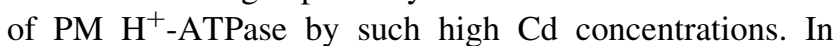
trying to explain the effect of $\mathrm{FC}$ on $\mathrm{Cd}^{2+}$ accumulation in maize coleoptile segments, we assumed that $\mathrm{Cd}$ enters plant cells by way of $\mathrm{Ca}$ channels. Such a possibility has previously been described in plants and animals (PerfusBarbeoch et al. 2002 and literature therein). It is also known that activation of PM $\mathrm{Ca}$ channels and resulting $\mathrm{Ca}^{2+}$ influx depends on the $E_{\mathrm{m}}$ (for review see White 2000).

Taking into account that $\mathrm{FC}$ combined with $\mathrm{Cd}^{2+}$ at $100 \mu \mathrm{M}$ hyperpolarized $E_{\mathrm{m}}$ potential of the parenchymal cells (Table 1), it could be suggested that the Ca channels (probably depolarization-activated $\mathrm{Ca}^{2+}$ channels) are closed, thus decreasing $\mathrm{Cd}^{2+}$ influx into the cell. These findings are also supported by the fact that $\mathrm{FC}$ alone, or FC combined with $\mathrm{Cd}^{2+}$, decreased $\mathrm{Ca}$ content cells of coleoptile segments (Fig. 6). To prove our hypothesis that $\mathrm{Cd}^{2+}$ enters plant cells by way of $\mathrm{Ca}$ channels, we performed experiments with Ca-channel blockers ( $\mathrm{La}$ and Ver) and also with TEA chloride, which blocks potassium channels (Thiel et al. 1996; Claussen et al. 1997; White 2000; Tode and Lüthen 2001; Osawa and Matsumoto 2002; Lindberg et al. 2004; Shishova and Lindberg 2004) as well as Ca channels (White 2000; White et al. 2002). As indicated in Fig. 7, both La and Ver significantly decreased $\mathrm{Cd}^{2+}$ content in maize coleoptile segments. This finding is probably due to the blocking of $\mathrm{Ca}$ channels, by which $\mathrm{Cd}^{2+}$ ions enter cells. TEA chloride was not used in growth experiments because it inhibits FC-induced growth in maize coleoptile segments, probably as a result of $\mathrm{K}^{+}$ inward rectifying (ZMK1) channel inhibition (Philippar et al. 1999; Tode and Lüthen 2001; Siemieniuk 2006). However, it was found that TEA chloride was much more effective than FC in (1) PM hyperpolarization (Table 1), (2) decreasing $\mathrm{Cd}$ and $\mathrm{Ca}$ content in coleoptile segments treated with $\mathrm{Cd}^{2+}$ (Figs. 5, 6), and (3) recovery of $E_{\mathrm{m}}$ after its depolarization induced by the highest $\mathrm{Cd}^{2+}$ concentration (Table 1). Our data showing the effects of TEA chloride on $E_{\mathrm{m}}$ of plant cells are consistent with results obtained by Olivetti et al. (1995) and Siemieniuk (2006), who showed that TEA chloride hyperpolarized the $E_{\mathrm{m}}$ of root cap cells of Phaseolus vulgaris and parenchymal cells of Zea mays coleoptile segments, respectively. It also has been shown previously (Pavlovkin et al. 2006) that FC added to $\mathrm{Cd}^{2+}$-treated $(1 \mathrm{mM})$ cortical cells in maize roots accelerated recovery of $E_{\mathrm{m}}$.

The results reported by Lindberg et al. (2004) with protoplasts isolated from wheat seedlings should also be mentioned. These investigators showed that $\mathrm{Cd}^{2+}$ uptake into the cytosol of wheat leaves and root protoplasts was inhibited by $\mathrm{Ca}$ and potassium chloride as well as by Ver and TEA chloride (inhibitors of $\mathrm{Ca}$ and potassium channels, respectively). They suggested that $\mathrm{Cd}$ uptake into the cytosol of wheat protoplasts is mediated in part by channels permeable to $\mathrm{Ca}$ and potassium and is dependent on $E_{\mathrm{m}}$. Lindberg et al. (2004) suggested that $\mathrm{Cd}^{2+}$ can be partly taken up by $\mathrm{K}^{+}$-channels because TEA chloride inhibits $\mathrm{Cd}^{2+}$ uptake. However TEA chloride could also inhibit PM $\mathrm{Ca}^{2+}$-channels (White 2000; White et al. 2002) excluding a role of $\mathrm{K}^{+}$-channels in decreasing $\mathrm{Cd}^{2+}$ uptake. Our results with TEA chloride also support this hypothesis because TEA chloride significantly diminished uptake of $\mathrm{Cd}^{2+}$ and $\mathrm{Ca}^{2}$. Because TEA chloride inhibits FC-induced growth (Tode and Lüthen 2001; Siemieniuk 2006), probably as a result of ZMK1 channel inhibition, it is unlikely that $\mathrm{Cd}^{2+}$ enters the cells by way of $\mathrm{K}^{+}$-channels. We showed that hyperpolarization of PM, rather than its depolarization observed in the presence of metabolic inhibitors and TEA chloride (Lindberg et al. 2004), is responsible for decreasing $\mathrm{Cd}^{2+}$ uptake by coleoptile segments.

The results presented here are generally in agreement with data obtained by Perfus-Barbeoch et al. (2002), who showed in patch-clamp experiments with Vicia faba guard cell protoplasts that $\mathrm{PM} \mathrm{K}^{+}$-channels were insensitive to external $\mathrm{Cd}^{2+}$ application, whereas $\mathrm{Ca}^{2+}$-channels were found to be permeable to $\mathrm{Cd}^{2+}$. They also showed that $\mathrm{Cd}^{2+}$ enters cells by way of hyperpolarization-activated $\mathrm{Ca}^{2+}$-channels. In contrast to Perfus-Barbeoch et al. (2002), we suggest that $\mathrm{Cd}^{2+}$ enters the cells of maize coleoptile segments through depolarization-activated $\mathrm{Ca}^{2+}$-channels. Such channels have been characterized from suspension cultures of mesophyll and root cells (Thuleau et al. 1994a, b; Pineros and Tester 1997; White 2000). All of them are activated at voltages less negative than $-140 \mathrm{mV}$.

In conclusion, the results presented in this article demonstrate that the mechanism by which FC counteracts the toxic effects of $\mathrm{Cd}^{2+}$ (except for $1000 \mu \mathrm{M} \mathrm{Cd}^{2+}$ ) on the growth of maize coleoptile segments involves both stimulation of $\mathrm{PM} \mathrm{H}{ }^{+}$-ATPase activity by $\mathrm{FC}$ and $\mathrm{Cd}^{2+}$-permeable, voltage-dependent $\mathrm{Ca}$ channels, which are blocked by FC- and TEA chloride-induced PM hyperpolarization.

Acknowledgments We thank Iza K. Radecka and Terence J. Bartlett (University of Wolverhampton, School of Applied Sciences, Wolverhampton, GB) for critical reading of this manuscript and correcting the English text. 
Open Access This article is distributed under the terms of the Creative Commons Attribution Noncommercial License which permits any noncommercial use, distribution, and reproduction in any medium, provided the original author(s) and source are credited.

\section{References}

Aidid SB, Okamoto H (1992) Effects of lead, cadmium and zinc on the electric membrane potential at the xylem/symplast interface and cell elongation of Impatiens balsamina. Environ Exp Bot 32:439-448

Astolfi S, Zuchi S, Chiani A, Passera C (2003) In vivo and in vitro effects of cadmium on $\mathrm{H}^{+}$ATPase activity of plasma membrane vesicles from oat (Avena sativa L.) roots. J Plant Physiol 160:387-393

Baunsgaard L, Fuglsang AT, Jahn T, Korthout HAAJ, De Boer AH, Palmgren MG (1998) The 14-3-3 proteins associate with the plasma membrane $\mathrm{H}^{+}$-ATPase to generate a fusicoccin binding complex and a fusicoccin responsive system. Plant J 13:661-671

Claussen M, Lüthen H, Blatt M, Böttger M (1997) Auxin-induced growth and its linkage to potassium channels. Planta 201:227234

Cleland RE, Prins HBA, Harper JR, Higinbotham W (1977) Rapid hormone-induced hyperpolarization of the oat coleoptile transmembrane potential. Plant Physiol 59:395-397

Das P, Samantaray S, Rout GR (1997) Studies on cadmium toxicity in plant: a review. Environ Pollut 98:29-36

Di Cagno R, Guidi L, Stefani A, Soldatini GF (1999) Effects of cadmium on growth of Helianthus annuus seedlings: physiological aspects. New Phytol 144:65-71

Felle $\mathrm{H}$ (1989) $\mathrm{pH}$ as a second messenger in plants. In: Boss WF, Morre DJ (eds) Second messengers in plant growth and development. Liss, New York, pp 145-166

Fodor E, Szabó-Nagy A, Erdei L (1995) The effects of cadmium on the fluidity and $\mathrm{H}^{+}$-ATPase activity of plasma membrane from sunflower and wheat. J Plant Physiol 147:87-92

Fuglsang AT, Visconti S, Drumm K, Jahn T, Stensballe A, Mattei B et al (1999) Binding of 14-3-3 protein to the plasma membrane $\mathrm{H}^{+}$-ATPase AHA2 involves the three $\mathrm{C}$-terminal residues $\operatorname{Tyr}(946)$-thr-Val and requires phosphorylation of $\operatorname{Thr}(947)$. J Biol Chem 274:36774-36780

Gonçalves JF, Goldschmidt FA, Maldaner J, Pereira LB, Tabaldi LA, Rauber R et al (2009) Cadmium and mineral nutrient accumulation in potato plantlets growth under cadmium stress in two different experimental culture conditions. Plant Physiol Biochem 47:814-821

Hager A (2003) Role of the plasma membrane $\mathrm{H}^{+}$-ATPase in auxininduced elongation growth: historical and new aspects. J Plant Res 116:483-505

Hager A, Debus G, Edel HG, Stransky H, Serrano R (1991) Auxin induces exocitosis and the rapid synthesis of a high turnover pool of plasma membrane $\mathrm{H}^{+}$-ATPase. Planta 185:527-537

Jahn T, Fuglesang AT, Olsson A, Bröntrup IM, Collinge DB, Volkmann D et al (1997) The 14-3-3 protein interacts directly with the C-terminal region of the plant plasma membrane $\mathrm{H}^{+}$-ATPase. Plant Cell 9:1805-1814

Kabała K, Janicka-Russak M, Burzyński M, Kłobus G (2008) Comparison of heavy metal effect on the proton pumps of plasma membrane and tonoplast in cucumber root cells J. Plant Physiol 165:278-288

Karcz W, Burdach Z (2002) A comparison of the effects of IAA and 4-Cl-IAA on growth, proton secretion and membrane potential in maize coleoptile segments. J Exp Bot 53:1089-1098
Karcz W, Burdach Z (2007) Effects of temperature on growth, proton extrusion and membrane potential in maize (Zea mays L) coleoptile segments. Plant Growth Regul 52:141-150

Karcz W, Kurtyka R (2007) Effect of cadmium on growth, proton extrusion and membrane potential in maize coleoptile segments. Biol Plantarum 51:713-719

Karcz W, Stolarek J, Pietruszka M, Małkowski E (1990) The doseresponse curves for IAA induced elongation growth and acidification of the incubation medium of Zea mays L. coleoptile segments. Physiol Plant 80:257-261

Karcz W, Stolarek J, Lekacz H, Kurtyka R, Burdach Z (1995) Comparative investigation of auxin and fusicoccin-induced growth and $\mathrm{H}^{+}$-extrusion in coleoptile segments of Zea mays L. Acta Physiol Plant 17:3-8

Kennedy CD, Gonsalvez FAN (1987) The action of divalent zinc, cadmium, mercury, copper and lead on the trans-root potential and $\mathrm{H}^{+}$efflux of excised roots. $\mathrm{J}$ Exp Bot 38:800-817

Kurtyka R, Małkowski E, Kita A, Karcz W (2008) Effect of calcium and cadmium on growth and accumulation of cadmium, calcium, potassium and sodium in maize seedlings. Pol J Environ Stud 17:51-56

Kutschera U, Schopfer P (1985) Evidence for the acid-growth theory of fusiccocin action. Planta 163:494-499

Lindberg S, Wingstrand G (1985) Mechanism for $\mathrm{Cd}^{2+}$ inhibition of $\left(\mathrm{K}^{+}+\mathrm{Mg}^{2+}\right)$ ATPase activity and $\mathrm{K}^{+}\left({ }^{86} \mathrm{Rb}^{+}\right)$uptake in roots of sugar beet (Beta vulgaris). Physiol Plant 63:181-186

Lindberg S, Landberg T, Greger M (2004) A new method to detect cadmium uptake in protoplasts. Planta 219:526-532

Llamas A, Ullrich CI, Sanz A (2000) $\mathrm{Cd}^{2+}$ effects on transmembrane electrical potential difference, respiration and membrane permeability of rice (Oryza sativa L.) roots. Plant Soil 219:21-28

Lüthen H, Bigdon M, Böttger M (1990) Reexamination of the acid growth theory of auxin action. Plant Physiol 93:931-939

Marré E (1979) Fusicoccin: a tool in plant physiology. Annu Rev Plant Physiol 30:273-288

Nouairi I, Ammar WB, Youssef NB, Daoud DBM, Ghorbal MH, Zarrouk M (2006) Comparative study of cadmium effects on membrane lipid composition of Brassica juncea and Brassica napus leaves. Plant Sci 170:511-519

Oecking C, Hagemann K (1999) Association of 14-3-3 proteins with the C-terminal autoinhibitory domain of the plant plasma membrane $\mathrm{H}^{+}$-ATPase generates a fusicoccin-binding complex. Planta 207:480-482

Olivetti GP, Cumming JR, Etherton B (1995) Membrane potential depolarization of root cap cells precedes aluminum tolerance in snapbean. Plant Physiol 109:123-129

Osawa H, Matsumoto H (2002) Aluminium triggers malate-independent potassium release via ion channel from the root apex in wheat. Planta 215:405-412

Pál M, Horváth E, Janda T, Páldi E, Szalai G (2006) Physiological changes and defense mechanisms induced by cadmium stress in maize. J Plant Nutr Soil Sci 169:1-8

Palmgren MG (1998) Proton gradients and plant growth: role of the plasma membrane $\mathrm{H}^{+}$-ATPase. Adv Bot Res 28:1-70

Pavlovkin J, Luxová M, Mistríková I, Mistrík I (2006) Short- and long-term effects of cadmium on transmembrane electric potential $\left(E_{\mathrm{m}}\right)$ in maize roots. Biol Bratislava 61:109-114

Perfus-Barbeoch L, Leonhardt N, Vavasseur A, Forestier C (2002) Heavy metal toxicity: cadmium permeates through calcium channels and disturbs the plant water status. Plant J 32:539-548

Philippar K, Fuchs I, Luthen H, Hoth S, Bauer CS, Haga K et al (1999) Auxin-induced $\mathrm{K}^{+}$channel expression represents an essential step in coleoptile growth and gravitropism. PNAS 96:12186-12191

Pineros M, Tester M (1997) Calcium channels in greater plant cells: selectivity, regulation and pharmacology. J Exp Bot 48:551-577 
Ros R, Cooke DT, Burden RS, James CS (1990) Effects of the herbicide MCPA, and the heavy metals, cadmium and nickel on the lipid composition, $\mathrm{Mg}^{2+}$-ATPase activity and fluidity of plasma membranes from rice, Oryza sativa (cv. Bahia) shoots. J Exp Bot 41:457-462

Ros R, Morales A, Segura J, Picazo I (1992) In vivo and in vitro effects of nickel and cadmium on the plasmalemma ATPase from rice (Oryza sativa L.) shoots and roots. Plant Sci 83:1-6

Rubio MI, Escrig I, Martinez-Cortina C, López-Benet FJ, Sanz A (1994) Cadmium and nickel accumulation in rice plants. Effects on mineral nutrition and possible interactions of abscisic and gibberellic acids. Plant Growth Regul 14:151-157

Rück A, Palme K, Venis MA, Napier RM, Felle H (1993) Patchclamp analysis establishes a role for an auxin binding protein in the auxin stimulation of plasma membrane current in Zea mays protoplasts. Plant J 4:41-46

Sandalio LM, Dalurzo HC, Gómez M, Romero-Puertas MC, del Río LA (2001) Cadmium-induced changes in the growth and oxidative metabolism of pea plants. J Exp Bot 52:2115-2126

Sanità di Toppi L, Gabbrielli R (1999) Response to cadmium in higher plans. Environ Exp Bot 41:105-130

Seregin IV, Ivanov VB (2001) Physiological aspects of cadmium and lead toxic effects on higher plants. Russ J Plant Physiol 48:523-544

Shishova M, Lindberg S (2004) Auxin induces an increase of $\mathrm{Ca}^{2+}$ concentration in the cytosol of wheat leaf protoplasts. J Plant Physiol 161:937-945
Siemieniuk A (2006) Doctoral thesis, The effect of potassium and calcium on IAA and FC-induced elongation growth of maize (Zea mays L.) coleoptile segments. University of Silesia, Katowice, Poland

Thiel G, Brüdern A, Gradmann D (1996) Small inward rectifying $\mathrm{K}^{+}$ channels in coleoptiles: inhibition by external $\mathrm{Ca}^{2+}$ and function in cell elongation. J Membr Biol 149:9-20

Thuleau P, Moreau M, Schroeder JI, Ranjeva R (1994a) Recruitment of plasma membrane voltage-dependent calcium-permeable channels in carrot cells. EMBO J 13:5843-5847

Thuleau P, Ward JM, Ranjeva R, Schroeder JI (1994b) Voltagedependent calcium-permeable channels in the plasma membrane of a higher plant cells. EMBO J 13:2970-2975

Tode K, Lüthen H (2001) Fusicoccin- and IAA-induced elongation growth share the same pattern of $\mathrm{K}^{+}$dependence. J Exp Bot $52: 251-255$

White PJ (2000) Calcium channels in higher plant. Biochim Biophys Acta 1465:171-189

White PJ, Bowen HC, Demidchik V, Nichols C, Davies JM (2002) Genes for calcium-permeable channels in the plasma membrane of plant root cells. Biochim Biophys Acta 1564:299-309

Wójcik M, Tukiendorf A (2005) Cadmium uptake, localization and detoxification in Zea mays. Biol Plantarum 49:237-245

Würtele M, Jelich-Ottmann Ch, Wittinghofer A, Oecking C (2003) Structural view of a fungal toxin acting on a 14-3-3 regulatory complex. EMBO J 22:987-994 